\title{
Pulsed Wave-Doppler Ultrasonographic Evaluation of the Mammary Blood Flow in the Ewe
}

\author{
G. PICCIONE, A. ARCIGLI, A. ASSENZA, M. PERCIPALlE, G. CAOLA \\ Department of Morphology, Biochemistry, Physiology and Animal Productions - Section of Veterinary \\ Physiology - Faculty of Veterinary Medicine - University of Messina - Polo \\ Universitario dell'Annunziata - 98168 Messina \\ Received November 27, 2002 \\ Accepted February 11, 2004
}

Abstract

Piccione G., A. Arcigli, A. Assenza, M. Percipalle, G. Caola: Pulsed Wave-Doppler Ultrasonographic Evaluation of the Mammary Blood Flow in the Ewe. Acta Vet. Brno 2004, 73: 23-27.

The authors investigated mammary blood flow by means of a pulsed wave-Doppler ultrasonographic technique in ewes during different production phases. Three groups ( $\mathrm{Ga}, \mathrm{Gb}$, and Gc, five animals in each) of Comisana sheep were used in the experiment. Ga sheep were milked twice a day by means of a milking machine; Gb sheep nursed their lambs, and group Gc was made up of dry sheep. Recordings of systolic and diastolic pressure of the left and right lateral mammary veins (SSLMV and DSLMV) and arteries (SSLMA and DSLMA) were carried out by means of a Pulse Doppler system. Recordings for Ga were taken before and after milking in the morning and in the afternoon. In Gb and Gc sheep, recordings were taken only in the morning and in the afternoon. Statistical analysis was carried out of the mean values of the recordings taken as mentioned above and the Student's $t$-test for paired data was used. A statistically significant difference was found in Ga recordings carried out before and after morning $(0.05<\mathrm{P}<0.001)$ and afternoon $(0.05<\mathrm{P}<0.01)$ milking. Ga morning mean flow speeds were between $7.00 \pm 1.87$ and $12.20 \pm 2.28 \mathrm{~cm} / \mathrm{sec}$ for SSLMV; $19.70 \pm 3.51$ and $32.40 \pm 4.77 \mathrm{~cm} / \mathrm{sec}$ for SSLMA; $2.40 \pm 0.55$ and $5.60 \pm 0.55 \mathrm{~cm} / \mathrm{sec}$ for SDLMV, and $4.00 \pm 1.00$ and $8.20 \pm 3.83 \mathrm{~cm} / \mathrm{sec}$ for SDLMA. Ga afternoon mean flow speeds were between $8.80 \pm 1.30$ and $12.60 \pm 2.30 \mathrm{~cm} / \mathrm{sec}$ for SSLMV; 20.20 \pm 2.86 and $29.20 \pm 5.76 \mathrm{~cm} / \mathrm{sec}$ for SSLMA; $2.40 \pm 0.55$ and $6.40 \pm 2.30 \mathrm{~cm} / \mathrm{sec}$ for SDLMV, and $3.20 \pm 0.84$ and $7.00 \pm 2.83 \mathrm{~cm} / \mathrm{sec}$ for SDLMA. No significant differences were found between morning and afternoon recordings in $\mathrm{Gb}$ and $\mathrm{Gc}$ sheep or between systolic and diastolic speeds of right and left mammary veins and arteries in the 3 groups.

Our results showed that mechanical milking may influence the vascular mammary flow. It may lower the intramammary pressure, increase blood flow and activate mammary metabolism. Furthermore ultrasonographic techniques could be useful for functional assessment of mammary gland activity.

Pulsed doppler, systolic speed, diastolic speed, lactation, dry period, Ovis aries

It is known that changes in the functional and physiological state of the mammary gland are related to mammary blood flow. Nutrient uptake and metabolic by-product removal in the gland occur by means of blood flow and arterial-venous difference. Therefore accurate measurements of mammary blood flow are useful for the assessment of nutrient and hormone uptake (Kensinger et al. 1983).

Several investigations have been carried out in ruminants in order to study vascular flows and to provide information about the functional condition of the mammary gland during lactation. Four different techniques for the assessment of mammary blood flow were compared. Continuous thermo-dilution and electromagnetic induction techniques were very accurate, but harmful and difficult (Linzell 1970; Rey nolds et al.1968) while antipyrine absorption and nitrous oxide diffusion are not extremely reliable.

Address for correspondence:

Prof. Giuseppe Piccione

Department of Morphology, Biochemistry, Physiology and Animal Production

(

98168 Messina - Italy
Phone: +39090357221

Fax: +39090 356195

E-mail: Giuseppe.Piccione@unime.it

E-mail: Giuseppe.Piccione@ unime.it 


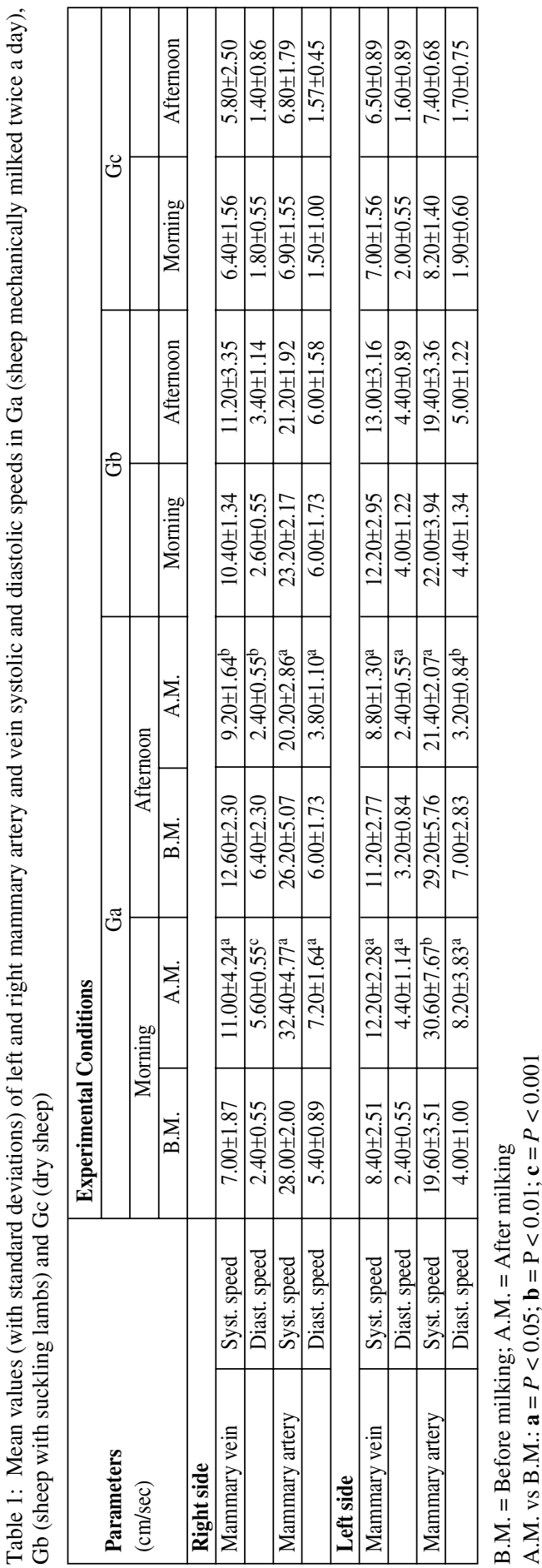

Doppler ultrasonographic method, as described by Drost (1978), is useful for mammary blood flow recordings. It is based on ultrasound transit and its probe does not have to be surgically applied to the examined blood vessel as in other Doppler techiques (Gorew it et al. 1989).

Today Doppler ultrasonographic method supplies useful haemodynamic data. It plays a leading role in vascular function investigations because it is a reliable, easy to run and harmless method.

Circulatory phenomena are complex organic functions that may be influenced by several factors such as blood viscosity, vascular walls elasticity, rhythm of the cardiac pump discontinuous activity, various resistance to blood flow in tissues, and spontaneous or induced vasomotor responses (Dauzat 1988).

On the basis of this knowledge we investigated mammary blood flow by means of a pulsed wave-Doppler ultrasonographic technique.

\section{Materials and Methods}

Ten Comisana sheep (2-year-old, 45th day of lactation, mean milk production: $500 \mathrm{ml} / \mathrm{day}$ ) and five Comisana sheep (3-year-old, dry subjects) were used for our study. All animals were clinically healthy and well fed.

Animals were stabled in paddocks of Istituto Zootecnico Sperimentale della Sicilia's facilities and were divided into three groups $(\mathrm{Ga}, \mathrm{Gb}$, and $\mathrm{Gc} ; 5$ subjects each). Subjects in Ga were in their first

lactation, and were fed twice a day a unifeed diet $(400$ $\mathrm{g} /$ subject/day of pellet feed $18 \%$ of proteins, 1.8-2.0

$\mathrm{kg} / \mathrm{subject/day} \mathrm{of} \mathrm{hay} \mathrm{and} \mathrm{water}$ ad libitum). Animals II were milked twice a day (at $07.00 \mathrm{~h}$ and at $17.00 \mathrm{~h}$ ) by means of a milking machine (Laval Alpha- De Laval, UK). Subjects in Gb were in their first lactation, nursed their lambs, and were fed twice a day a unifeed diet $(400 \mathrm{~g} / \mathrm{subject} / \mathrm{day}$ of pellet feed $16 \%$ of proteins, $1.8-2.0 \mathrm{~kg} / \mathrm{subject} / \mathrm{day}$ of hay and water ad libitum). Subjects in Gc delivered for the first time and at the time of our study were dry; these subjects were fed a unifeed diet $(200 \mathrm{~g} / \mathrm{subject/day} \mathrm{of}$ pellet feed $15 \%$ of protein, $1 \mathrm{~kg} / \mathrm{subject/day}$ of hay and water ad libitum).

In all subjects recordings of speeds of systolic and diastolic flow of right and left lateral mammary veins and arteries (Barone 1983) were carried out by means of a Pulsed Doppler System (PW-mode, 8 $\mathrm{MHz}$ probe, $50 \%$ gain, 7.5 power and $10 \mathrm{~mm}$ depth). The probe was placed on the blood vessel to clearly 
visualize blood flow. Recordings for Ga were taken before and after milking in the morning and in the afternoon. $\mathrm{Gb}$ and Gc recordings were taken twice a day (once in the morning and once in the afternoon). Recordings were carried out with animal in lateral (right and left) recumbency. Seven days prior to our investigation, all ewes underwent an adaptation period consisting of lying animals in lateral recumbency and handled (including recording of heart rate in order to evaluate stress) in a Doppler equipment. During our recordings of vascular flow speeds, heart rate in the sheep was between 66 and 129 beats/min (physiological values for this species) (Hecker 1983). In order to reduce as much as possible the examination bias, handlings during the adaptation periods and recordings were done by the same well-experienced operator. Since intragroup variance showed no statistical difference, statistical analysis was carried out on mean values of the recorded parameters. In order to obtain a statistical significance the following recordings taken on right and left mammary veins and arteries were compared: for Ga, recordings taken in the morning and in the afternoon, before and after the milking; in Gb and Gc, recordings taken in the morning and in the afternoon. Student's $t$-test for paired data was applied to these values.

\section{Results}

Table 1 shows mean values of the mammary vascular index in all groups, expressed in $\mathrm{cm} / \mathrm{sec}$ with standard deviation (SD) and statistical significance obtained comparing recordings taken during the different moments in left and right recumbency in $\mathrm{Ga}, \mathrm{Gb}$, and Gc.

Statistically significant differences were found in Ga recordings carried out before and after morning $(0.05<P<0.001)$ and afternoon $(0.05<P<0.01)$ milkings. No significant differences were found between morning and afternoon recordings in $\mathrm{Gb}$ and $\mathrm{Gc}$ or between systolic and diastolic speeds of right and left mammary veins and arteries in the 3 groups.

\section{Discussion}

Analysis of the results showed changes in systolic and diastolic mammary lateral veins and arteries speed between morning and afternoon milking in $\mathrm{Ga}$. In particular, the significant increase of the flow may be due to a decrease in intramammary pressure. Ga morning mean flow speeds were between $7.00 \pm 1.87$ and $12.20 \pm 2.28 \mathrm{~cm} / \mathrm{sec}$ for SSLMV; $19.60 \pm 3.51$ and $32.40 \pm 4.77 \mathrm{~cm} / \mathrm{sec}$ for SSLMA; $2.40 \pm 0.55$ and $5.60 \pm 0.55 \mathrm{~cm} / \mathrm{sec}$ for SDLMV, and $4.00 \pm 1.00$ and $8.20 \pm 3.83 \mathrm{~cm} / \mathrm{sec}$ for SDLMA. Ga afternoon mean flow speeds were between $8.80 \pm 1.30$ and $12.60 \pm 2.30 \mathrm{~cm} / \mathrm{sec}$ for SSLMV; $20.20 \pm 2.86$ and $29.20 \pm 5.76 \mathrm{~cm} / \mathrm{sec}$ for SSLMA; $2.40 \pm 0.55$ and $6.40 \pm 2.30 \mathrm{~cm} / \mathrm{sec}$ for SDLMV, and 3.20 \pm 0.84 and $7.00 \pm 2.83 \mathrm{~cm} / \mathrm{sec}$ for SDLMA. The inverse linear relationship among the mammary blood flow and the intramammary pressure is well-known (Pearl et al. 1973). Furthermore, intramammary pressure decreases occurring at the beginning of lactation may be responsible for the postpartum mammary blood flow increase (Reynolds 1969).

Pressure modifications within a non-expansible organ may be a leading factor in the local blood flow control in that particular organ. This theory gained growing interest as it was demonstrated that tissue pressure plays an important role in determining vascular resistance in the kidney.

By developing a model that illustrates the effects of transmural pressure on blood flow, it was possible to demonstrate that if an extravascular pressure value is in-between arterial and venous pressure values, flow will be proportional to the difference between the arterial and extravascular pressure (Haddy et al. 1965; Hinshaw et al. 1959). This supports the evidence for a linear relationship between intramammary pressure and mammary blood flow.

Results obtained in sheep with suckling lambs (Gb) confirm the influence of intramammary pressure on mammary blood flow. Interestingly, this group reveals no differences between morning and afternoon mammary blood flow values as a consequence of constant udder stimulation by the suckling lamb. Gb morning mean flow speeds were between $10.40 \pm 1.34$ and $12.20 \pm 2.95 \mathrm{~cm} / \mathrm{sec}$ for SSLMV; $22.00 \pm 3.94$ and $23.20 \pm 2.17$ 
$\mathrm{cm} / \mathrm{sec}$ for SSLMA; $2.60 \pm 0.55$ and $4.00 \pm 1.22 \mathrm{~cm} / \mathrm{sec}$ for SDLMV, and $4.40 \pm 1.34$ and $6.00 \pm 1.73 \mathrm{~cm} / \mathrm{sec}$ for SDLMA. Gb afternoon mean flow speeds were between $11.20 \pm 3.35$ and $13.00 \pm 3.16 \mathrm{~cm} / \mathrm{sec}$ for SSLMV; $19.40 \pm 3.36$ and $21.20 \pm 1.92 \mathrm{~cm} / \mathrm{sec}$ for SSLMA; $3.40 \pm 1.14$ and $4.40 \pm 0.89 \mathrm{~cm} / \mathrm{sec}$ for SDLMV , and $5.00 \pm 1.22$ and $6.00 \pm 1.58 \mathrm{~cm} / \mathrm{sec}$ for SDLMA.

In mammary physiology, individual differences in venous anastomosis and between lactating and dry animals must always be considered. Except for the lactation period, sheep and goat udders are drained only by external pudenda veins and the blood carried by the abdominal subcutaneous veins. When mammary glands are active their valves are ineffective and bloodstream flows toward the chest; consequently udders are drained by both the external pudenda and the subcutaneous abdominal veins (B arone 1983).

In Gc, very low circulatory speeds have been recorded $(2.00 \pm 0.55$ and $8.20 \pm 1.40 \mathrm{~cm} / \mathrm{sec}$ for lateral mammary artery diastolic and systolic speed, and $1.00 \pm 0.45$ and $7.79 \pm 1.32$ $\mathrm{cm} / \mathrm{sec}$ for lateral mammary vein diastolic and systolic speed). In dry animals, the lower and steadier mammary blood flow values recorded can be explained in terms of gland inactivity and of the physiological peculiarity mentioned above; this agrees with earlier research carried out on dry Holstein cows (Kensinger et al. 1983).

The analysis of the specific literature so far indicates that this approach has not been used in sheep as yet. Therefore, the discussion of our results cannot profit from a comparison with other studies in this species.

It can be stated that mammary flow velocity values recorded in right and left mammary arteries and veins in the sheep represent preliminary values. Further investigations are needed before using this technique also from a clinical point of view.

Our results showed that mechanical milking may influence vascular mammary flow. It may lower intramammary pressure, increase blood flow and activate mammary metabolism. Furthermore ultrasonographic techniques could be useful for functional assessment of mammary gland activity as already anticipated for the cow (Thivierge et al. 2000).

\section{Pulzní doppler-ultrasonografické vyšetření rychlosti proudění krve v mléčné žláze u ovce}

Autoři sledovali průtok krve $\mathrm{v}$ mléčné žláze pomocí pulzní doppler-ultrasonografické techniky u bahnic během různých produkčních fází. $V$ experimentu byly použity 3 skupiny ovcí plemene Comisana (Ga, Gb a Gc, po 5 zvířatech). Ga ovce byly dojeny dvakrát denně pomocní dojicího stroje, Gb ovce měli pod sebou jehňata, a skupina Gc byla sestavena ze zasušených ovcí. Záznamy systolického a diastolického tlaku levé a pravé laterální žíly mléčné žlázy (SSLMV a DSLMV) a arterií (SSLMA a DSLMA) byly provedeny pomocí pulzního doppler systému. Měření u Ga bylo provedeno před a po dojení ráno a odpoledne. U Gb a Gc ovcí byla měření prováděna pouze jednou ráno a jednou odpoledne. Získané výsledky byly statisticky vyhodnoceny a pro párová data byl použit Studentův $t$-test. Statisticky významné rozdíly byly zjištěny v měřeních skupiny Ga provedených před a po ranním $(0.05<P<0.001)$ a odpoledním $(0.05<P<0.01)$ dojení. Průměrný ranní průtok skupiny Ga se pohyboval mezi $7.00 \pm 1.87$ a $12.20 \pm 2.28 \mathrm{~cm} / \mathrm{s}$ pro SSLMV; $19.70 \pm 3.51$ a $32.40 \pm 4.77 \mathrm{~cm} / \mathrm{s}$ pro SSLMA; $2.40 \pm 0.55$ a $5.60 \pm 0.55 \mathrm{~cm} / \mathrm{s}$ pro SDLMV, a $4.00 \pm 1.00$ a $8.20 \pm 3.83 \mathrm{~cm} / \mathrm{s}$ pro SDLMA. Průměrný odpolední průtok této skupiny se pohyboval mezi $8.80 \pm 1.30 \mathrm{a} 12.60 \pm 2.30 \mathrm{~cm} / \mathrm{s}$ pro SSLMV; $20.20 \pm 2.86 \mathrm{a} 29.20 \pm 5.76 \mathrm{~cm} / \mathrm{s}$ pro SSLMA; $2.40 \pm 0.55$ a $6.40 \pm 2.30 \mathrm{~cm} / \mathrm{s}$ pro SDLMV, a $3.20 \pm 0.84$ a $7.00 \pm 2.83 \mathrm{~cm} / \mathrm{s}$ pro SDLMA.

Žádné signifikantní rozdíly nebyly zjištěny mezi ranními a odpoledními měřeními u Gb a Gc ovcí či mezi systolickým a diastolickým průtokem pravé a levé žíly a tepny mléčné žlázy.

Naše výsledky ukazují, že mechanické dojení může ovlivňovat průtok krve mléčnou žlázou, snižovat intramammární tlak, zvyšovat průtok krve a aktivovat metabolismus 
mléčné žlázy. Navíc ultrasonografická technika by mohla být užitečná pro funkční stanovení aktivity mléčné žlázy.

\section{References}

BARONE, R 1983: Anatomia comparata dei mammiferi domestici. Vol. 4. Splancnologia, Cap. $4^{\circ}$, pp 365-381 DAUZAT, M 1988: Applicazione dell'effetto doppler alla misurazione della velocità del sangue. In: Ultrasonografia vascolare. Piccin nuova libraria, pp. 5-6

DROST, CJ 1978 : Vessel diameter-independent volume flow measurements using ultrasound. Proc. San Diego Biomed. Symp 17: $299 \mathrm{p}$

GOREWIT, RC, AROMANDO, MC, BRISTOL, DG 1989: Measuring bovine mammary gland flow using a transit time ultrasonic flow probe. J Dairy Sci 72: 1918-1928

HADDY, FJ, SCOTT, JB 1965: Role of transmural pressure in local regulation of blood flow through kidney. Amer J Physiol 208: 825-831

HECKER, JF 1983: Cardiovascular physiology. In: HECKER J.F.: The sheep as an experimental animal. Academic Press, London, pp. 34-38

HINSHAW, LB, DAY, SB, CARLSON, CH 1959: Tissue pressure as a causal factor in the autoregulation of blood flow in the isolated perfused kidney. Amer J Physiol 197: 309-315

KENSINGER, MH, COLLIER, RJ, WILCOX, CJ, CATON, D 1983: Variability of resting mammary blood flow in non lactating Holstein cows. J. Dairy Sci 66: 1742-1746

LINZELL, JL 1970: Techniques for measuring nutrient uptake by the mammary glands. In: FALCONER, IR: Lactation. Butterworths, London, pp. 272-274

PEARL, SL, DOWNEY, HF, LEPPER, TL 1973: Intramammary pressure and mammary blood flow in lactating goats. J Dairy Sci 56: 1319-1323

REYNOLDS, M 1969: Relationship of mammary circulation and oxygen consumption to lactogenesis. In: REYNOLDS, M and FOLLEY, SJ: Lactogenesis. University of Pennsylvania Press, Philadelphia, pp. 145-151

REYNOLDS, M, LINZELL, JL, RASMUSSEN, F 1968: Comparison of four methods for measuring mammary blood flow in conscious goats. Amer J Physiol 214: 1415-1424

THIVIERGE, MC, PETITCLERC, D, BERNIER, JF, COUTURE, Y, LAPIERRE, H 2000: External pudic venous reflux into mammary vein in dairy cows. J Dairy Sci 83: 2230-2238 